\title{
彎 \\ LAND USE CHANGE OF AGRICULTURAL LAND IN A SPATIAL POLITICAL APPROACH
}

\author{
Rizca Yunike Putri \\ Study Program of Political Science, Social and Political Science Faculty \\ University of Wijaya Kusuma Surabaya \\ Email : rizcaputri.fisip@uwks.ac.id
}

\begin{abstract}
The effort to meet the community's need for space is to change the function of land which was originally used as agricultural activity to become a space for other community activities and is non-agricultural in nature, which we will later call the conversion of agricultural land. Generally, uncontrolled conversion of agricultural land functions, if not addressed, can lead to serious problems, among others, can threaten the capacity of food supply and environmental sustainability. The trend of increasing demand for land makes conversion of agricultural land difficult to avoid. The loss of agricultural land and the conversion of agricultural land to non-agricultural functions regardless of its form are indicators for the development of modern cities. The modern city which is synonymous with industrialization and the splendor of buildings will gradually remove agricultural areas and change the environmental ecosystem further. If viewed from an ecological point of view, of course this problem causes environmental imbalance which will have a negative impact on food security. But what about the conversion of agricultural land from the viewpoint of spatial politics?
\end{abstract}

Keywords : Agricultural land, land use changes, political spatial 


\section{INTRODUCTION}

A society that is more modern and developed both in terms of quality and quality of mindset will not only affect how they act and socialize, the physical aspects that support people's daily needs will inevitably follow the needs of the community whose needs are increasingly growing. One of the physical aspects that support the daily needs of modern society is space that can accommodate their daily routines. The forms of space required also vary, ranging from shelter or housing, space for economic activities such as office buildings, space for recreation such as entertainment spots and cafes, and space for mobility such as transportation and other public facilities.

Spatial development to support community needs does not only discuss issues of development and development, but also raw materials or space and the existence of land for space. Land is one of the main elements in supporting human life. Land functions as a place for humans to move to maintain their existence. The increasing use of land by humans, such as for housing, places to do business, fulfillment of public access and other facilities will cause the available land to become increasingly narrow. Not infrequently the need for this space requires the sacrifice of another land to change its function. Most of the changes in land use for community space needs are land that was originally used as agricultural land.

For example, the planning of the development of transportation facilities in the form of an alternative road to the Pantura route along PemalangPekalongan Regency to Batang Regency which is the northern coast route which is familiar to us with congestion, especially during the Eid homecoming.

From JPNN's observations, in the last few years Pekalongan has not added or opened new roads that can be used as alternatives. As a result, all vehicles, ranging from motorbikes, private cars, buses to trucks, have piled up on the main road in Pekalongan City. This is different from some areas, such as Pemalang, Batang and Kendal, which now have alternative roads that turn outside the city center (bypass). ${ }^{1}$

Actually, alternative roads already exist, but road facilities that are unable to accommodate vehicles with tonnage weight and poor road conditions have strengthened road users, especially large vehicles, to keep using the road along the Ahmad Dahlan intersection to the city limits, namely Jalan Batang. And to realize this plan requires the acquisition of agricultural land, which is mostly located in South Pekalongan Regency.

Apart from Pekalongan, the conversion of agricultural land has also occurred in Karanganyar, where every year around 158,000 hectares of agriculture are converted into housing areas, factories and toll roads. In addition, the rampant construction of villas has also influenced the lifestyle of the community, especially farmers who own land. Whereas in the past many farmers owned land and cultivated it themselves, now many have sold their land to developers and then chose to guard villas. Data from the Central Bureau of Statistics noted that $58 \%$ of the conversion of agricultural land to non-agricultural was used for housing and the remainder for non-agricultural economic activities and other public facilities. The National Land Agency indicates that land conversion is planned by local governments. This is due to the desire of local governments to develop the economy in their area by attracting investors to establish companies or build housing. ${ }^{2}$

In Bantul Regency which is known as an agri-

${ }^{1}$ Pemkabpekalongan.gov.id

${ }^{2}$ Muh. Taufiq Yuhry, “Alih Fungsi Lahan Pertanian ke Non Pertanian,” Dialektika, Edisi 08 (2011): 1-5. 
cultural cultivation area with a fairly high fertility rate supported by irrigation in most of the rice fields, it can be seen that the proportion of land use in 2009 according to data from the National Land Agency (BPN) Bantul Regency in 2010, only $36.9 \%$ of land remains. agriculture consisting of plantations and moor. Meanwhile, the majority of ex-land scattered in Bangunharjo and Panggungharjo Villages are used for housing and office buildings. ${ }^{3}$ The two villages are an area bordering the city of Yogyakarta. Other sub-districts where the conversion of agricultural land is most frequent are in Banguntapan, Kasihan and Bantul Districts.

In the urban sphere, we can take the example of the development of residential areas in West Surabaya, especially along the Lontar area to Lakarsantri, which is an agricultural area in the city of Surabaya, starting in the early 2000 s, residential developers began to look at residential areas to be built into residential areas because they are famous for their territory. which is quite high and never floods. Initially, the housing developer only took the north side, which is known for its rocky, infertile and unsuitable land contours for farming. But in just a period of five years starting in 2005 the settlement not only stood firm on the north side but had developed its wings on the south side which was famous for being fertile because it was traversed by rivers and until now it still has agricultural areas although its existence can be counted on the fingers. ${ }^{4}$

Of all the phenomena mentioned above and which have been briefly mentioned, the most striking thing about the effort to fulfill the community's need for space is to change the function of land which was originally an agricultural activity to become a space for other community activities and is non-agricultural in nature, which we will then referred to as the conversion of agricultural land. In general, uncontrolled conversion of agricultural land functions, if not addressed, can lead to serious problems, including threatening food supply capacity and environmental sustainability. The trend of increasing demand for land makes conversion of agricultural land difficult to avoid. ${ }^{5}$

In the urban spatial planning approach, the loss of agricultural land and the conversion of agricultural land to non-agricultural functions regardless of its form are indicators of modern urban development. The modern city which is synonymous with industrialization and the splendor of buildings will gradually remove agricultural areas and change the environmental ecosystem further.

From the subject side, the conversion of agricultural land is not only carried out by one individual subject (community masyarakat farmers, market bisnis business actors or the state/government officials) and not by action stimuli that shape social reality (land conversion). However, the relationship between actors is accompanied by a stimulus that forms an important role and impact in land conversion. So that it can be seen that there is the most striking relationship between the subjects, namely the market, namely business actors with the community, namely farmers and consumers of land converted from function that are mutually beneficial, even though the long-term community who is a farmer is affected the most negatively. Not to mention the impact on the environmental ecosystem.

If viewed from an ecological point of view, of course this problem causes environmental

\footnotetext{
${ }^{3}$ Ika Pewista dan Rika Harini, Faktor dan pengaruh alih fungsi lahan pertanian terhadap kondisi sosial ekonomi penduduk di kabupaten bantul. Kasus daerah perkotaan, pinggiran dan pedesaan tahun 2001-2010, 2010

${ }^{4}$ Pembatas antara area utara dan selatan adalah Jalan Raya Menganti yang posisinya ada di pertengahan dan merupakan jalur transportasi utama yang menghubungkan Wiyung hingga Menganti.

${ }^{5}$ Iqbal, M dan Sumaryanto. (2007). Strategi Pengendalian Alih Fungsi Lahan Pertanian Bertumpu Pada Partisipasi Masyarakat. Pusat Analisis Sosial Ekonomi dan Kebijakan Pertanian. Bogor : Pusat Analisis Sosial Ekonomi dan Kebijakan Pertanian.
} 
imbalances which will have a negative impact on food security. But what about the conversion of agricultural land from the perspective of spatial politics?

\section{LAND USE CHANGE}

Conversion of land functions or commonly referred to as land conversion is a change in the function of part or all of the land area from its original function (as planned) to another function which has negative impacts (problems) on the environment and the potential of the land itself. Conversion of land functions can also be interpreted as changes to other uses due to factors which broadly include the need to meet the needs of an increasing population and an increasing demand for a better quality of life.

According to the research conducted by Ilham, it is known that the factors causing the change of function from the external and internal sides of the farmers, namely the economic pressure during the economic crisis. This causes many farmers to sell their assets in the form of rice fields to meet their daily needs, which has the impact of increasing the conversion of paddy fields and increasing land tenure on the part of the owners of capital. Winoto stated that the agricultural land most vulnerable to conversion is rice fields. This is caused by:

1. The population density in rural areas that have dominant wetland agro-ecosystems is generally much higher than dry land agro-ecosystems, so that the population pressure on land is also higher.

2. Many rice fields are located close to urban areas.
3. As a result of previous development patterns. Rice field infrastructure is generally better than dry land areas

4. Development of infrastructure and facilities for settlements, industrial estates, and so on tends to take place rapidly in flat topographical areas, where in areas with such topography (especially in Java) the agricultural ecosystem is predominantly rice fields. ${ }^{6}$

Meanwhile, according to Irawan, there are two factors of land conversion, especially agricultural land, namely:

1. First, in line with the construction of a residential or industrial area in a land conversion location, accessibility in that location becomes increasingly conducive to industrial and residential development, which in turn encourages increased demand for land by other investors or land speculators so that the price of the surrounding land increases.

2. Second, an increase in land prices can further stimulate other farmers in the vicinity to sell land. ${ }^{7}$

According to Lestari, the process of changing the function of agricultural land to non-agricultural uses is caused by several factors. There are three important factors that cause the conversion of paddy fields, namely:

1. External Factors. Is a factor caused by the dynamics of urban growth, demography and economy.

2. Internal factors. This factor looks more at the side caused by the socio-economic conditions of land-user agricultural households.

3. Policy Factors. Namely aspects of regulations

\footnotetext{
${ }^{6}$ Winoto. (dalam Tinjauan Pustaka Universitas Sumatra Utara). 2005. Fakta Alih Fungsi Lahan. UNSU

${ }^{7}$ Irawan, Bambang. 2005. “Konversi Lahan Sawah: Potensi Dampak, Pola Pemanfaatannya, dan Faktor Determinan”. Bogor: Pusat Penelitian dan Pengembangan Sosial Ekonomi Pertanian.
} 
issued by the central and regional governments relating to changes in the function of agricultural land. Weaknesses in the regulatory or regulatory aspects themselves are mainly related to the issue of legal force, violation sanctions, and accuracy of land objects that are prohibited from being converted. ${ }^{8}$

And according to Wicaksono, other factors causing the conversion of agricultural land are mainly determined by:

1. The low value of land rent (land rent); Paddy fields around the development center are compared to land rent values for residential and industrial use.

2. Weak control functions and the enforcement of regulations by related institutions.

3. The prominence of the short-term goal, namely to increase local revenue (PAD) without considering the sustainability of natural resources in the autonomous era. ${ }^{9}$

The conversion of the function of paddy fields to non-agricultural uses can have an impact on the decline in agricultural production, and will have an impact on a broader dimension which is related to aspects of changes in the economic, social, cultural and political orientation of the community. The conversion of paddy fields has also resulted in the loss of opportunities for farmers to obtain income from their farming. According to research conducted by Widjanarko, the concentration of housing and industrial development in Java Island, on the one hand, adds to the opening of employment in the non-agricultural sector such as construction services and industry, but also has an unfavorable negative impact. These negative impacts include:

1. Reducing the area of paddy fields which results in a decrease in rice production, which interferes with the achievement of food self-sufficiency and creates food insecurity and results in shifting of employment from the agricultural to non-agricultural sectors. If the workforce is not fully absorbed, the unemployment rate will increase.

2. Government investment in the procurement of irrigation infrastructure and facilities is not optimally utilized.

3. The failure of investors to carry out housing and industrial development, as a result of the economic crisis, or due to miscalculations that have resulted in the unused land that has been acquired, thus increasing the area of idle land which in turn also creates social conflicts such as land looting.

The reduction in the rice field ecosystem, especially on the northern coast of Java Island, while the printing of new rice fields, which is very costly outside Java, such as in Central Kalimantan, does not show a positive impact. ${ }^{10}$

\section{HENRI LEFEBVRE THE PRODUCTION OF SPACE}

Lefebvre's argument in The Production of Space is space as a social product, or a complex social construction (based on social values and production of meaning) that affects spatial practices and perceptions of space. As a Marxist philosopher (but very critical of economic structuralism which was the dominant discourse at that time), Lefebvre

\footnotetext{
${ }^{8}$ Lestari. 2009. Faktor-faktor Terjadimya Alih Fungsi Lahan. Dalam Tinjauan Pustaka Universitas Sumatra Utara

${ }^{9}$ Wicaksono, R.B., 2007. Konversi Lahan Sawah ke Non Pertanian dalam Perkembangan Kota Nganjuk dan Pengaruhnya terhadap Perubahan Mata Pencaharian dan Pendapatan Petani. Diakses dari http://www.lib.itb.ac.id

${ }^{10}$ Widjanarko et al ( dalam ibrahim). 2006. Dampak Alih Fungsi Lahan.Universitas Sumatra Utara
} 
argues that social production of urban space is the basis for the reproduction of society, due to capitalism. Therefore, the concept of hegemony expressed by Antonio Gramsci is used as a reference to show how the social production of space is initiated by the hegemonic class as a tool to reproduce its domination. "Social space is a product of socialspace produced as a certain way of thinking and acting. It does not only mean production but also means control and then domination / power."

Lefebvre argues that all societies - and all modes of production - produce a certain space, a separate space. The city in the past cannot be understood only as a simple agglomeration of people and objects in a space - it has its own spatial practice (which is appropriate for the city - Lefebvre states that the intellectual climate that existed in the city of the past is closely related to social production in room).

Then, if each society produces its own space, each "social existence" gives hope or consecrates itself as a whole, but those that do not produce its own space will become an isolated group, an abstract odd community unable to get out of the shackles of ideology or culture. Based on this argument, Lefebvre criticized the Soviet city planner, who failed to produce a socialist space, only reproducing the modern urban design model (intervention in physical space, which is not sufficient to reach social space).

\section{DAVID HARVEY'S TIME-SPACE COMPRESSION}

David Harvey in his theory known as "time-space compression" which is generally understood as time and space. This theory can be said to be a certain perspective of humans today which is closely related to material progress that touches almost all aspects of life. The progress of this material is closely related to technological developments. In Harvey's view, the increasingly advanced technological achievements are inseparable from the capitalist mode of production. There are three descriptions of the capitalist mode of production adopted by Harvey from Marx's ideas, namely:

1. Growth oriented, capitalism is always oriented towards growth.

2. For maximum growth, there will always be exploitation of the workers behind it.

3. Capitalism basically requires a dynamic and innovative technological and organizational condition. ${ }^{11}$

Time and space are the basic categories of human existence. Control over money, time and space forms a substantial set of existing social forces. Harvey emphasized that an accurate map and time recorder equipped with control over time and space is a very important element in seeking as much material gain as possible. In the matter of matter, space and time, Harvey underlined two important things, namely:

1. The discovery and development of space and time measurements in business. It is described in terms of the use of time which was originally intended as a tool of clerical discipline to develop into a tool for the bourgeoisie in organizing business work in controlling workers. As well as a more detailed and comprehensive mapping of the globe, paving the way for exclusive use of space.

2. It finally realized the importance of constantly changing the way we use and understand time and space in terms of profit seeking. ${ }^{12}$

\footnotetext{
${ }^{11}$ Andrew Jones ,"Dialectics and difference: against Harvey's dialectical post-Marxism” Progress in Human Geography 23, no. 4 (1999): 529-555.

12 Opcit, 54.
} 


\section{ANALYSIS}

In Lefebvre's spatial approach, agricultural land can be perceived as a space and a place to grow crops (produce agricultural products) as well as a space to earn a living for farmers through farming. Agricultural land or paddy fields become farmers' tools to act to produce physical products, namely agricultural products and produce their social existence as farmers. Initially, the rice fields were just empty land, but with the need for a group of people who actualized themselves to cultivate the land and produce natural products, then a spatial meaning emerged that initially became agricultural land or rice fields.

The conversion of land functions in this approach could be a failure of farmers in maximizing the actualization and existence of social perceptions of the function of agricultural land. Of the many factors that have been put forward by many researchers on spatial planning that highlight the reduction of agricultural land due to land conversion, some of the main ones are pressure to meet housing needs which consequently is to use land that was originally agricultural land to become residential land, as well as pressure on economic needs for farmers. in fulfilling their daily life from agricultural products so that with practical thinking they can meet their economic needs and an agreement on a price they want to release their land. With the release of their land and being transferred to non-agricultural functions, automatically their social status as farmers can be used again and changed to another new status.

The ability of farmers who can actually consecrate and produce social roles to maximize the function of agricultural land space, but because there is an external perception in the form of domination of other functions of space which is interpreted as meeting the needs for residential development, public facilities or transportation, the function of agricultural land changes accordingly. with its new function.

Meanwhile, in another spatial approach, namely David Harvey's view, the conversion of agricultural land is one of the results of material progress in terms of development. It has been mentioned that urban progress is judged by the existence of modern spaces to support community activities and even minimize the existence of agricultural land, which is a symbol of an agrarian era that is far from modern industrial life. With the reduction of agricultural land, the development of spaces for industry and other community needs will have greater opportunities, which is one of the fulfillment of capitalist indicators, namely oriented to spatial growth and progress.

And in the end there will always be exploitation in the form of pressure on land owners and subjects who work on agricultural land. The form of exploitation is in the form of land grabbing in the form of buying and selling transactions, exchange of money to get a raw source of space which is then reprocessed to become a source of even greater profit. Even though the land owner gets the proceeds from selling his land, on the other hand, farm laborers who are cultivators of rice fields are marginalized because their livelihood places have turned into settlements or into industries or other things.

\section{CONCLUSION}

Agricultural land can be perceived as a space and a place for farming (producing agricultural products) and at the same time as a space to earn a living for farmers through farming. The conversion of land functions in this approach could be a failure of farmers in maximizing the actualization and existence of social perceptions of the function of agricultural land. The conversion of agricultural 
land is one of the results of material progress in terms of development. The progress of the city is judged by the existence of modern spaces to support community activities and even to minimize the existence of agricultural land which is a symbol of an agrarian era that is far from modern industrial life. There will always be exploitation in the form of pressure on land owners and the subjects who work on agricultural land. The form of exploitation is in the form of land grabbing in the form of sale and purchase transactions.

\section{REFERENCES}

Andrew Jones, 1999. "Dialectics and difference: against Harvey's dialectical post-Marxism" Progress in Human Geography 23, no. 4 (1999): 529-555.

Ilham, Dkk, 2003. Perkembangan dan Faktor-Faktor Yang Mempengaruhi Konversi Lahan Sawah Serta Dampak Ekonominya. IPB Press. Bogor.

Irawan, Bambang. 2005. "Konversi Lahan Sawah: Potensi Dampak, Pola Pemanfaatannya, dan Faktor Determinan". Bogor: Pusat Penelitian dan Pengembangan Sosial Ekonomi Pertanian. In Nugroho Budisantoso, 2002. "David Harvey: Time Space Compression dan Dunia Kapitalisme Lanjut," Majalah Filsafat Driyarkara, Tahun XXV/2002 no. 3, 52-64.

Iqbal, M dan Sumaryanto. 2007. Strategi Pengendalian Alih Fungsi Lahan Pertanian Bertumpu Pada Partisipasi Masyarakat. Pusat Analisis Sosial Ekonomi dan Kebijakan Pertanian. Bogor : Pusat Analisis Sosial Ekonomi dan Kebijakan Pertanian.

Lestari. 2009. Faktor-faktor Terjadimya Alih Fungsi Lahan. Dalam Penelitian Alih Fungsi Lahan di Pulau Jawa, Universitas Sumatra Utara. pengaruh alih fungsi lahan pertanian terhadap kondisi sosial ekonomi penduduk di kabupaten bantul. Kasus daerah perkotaan, pinggiran dan pedesaan tahun 2001-2010. 2010.

Wicaksono, R.B., 2007. Konversi Lahan Sawah ke Non Pertanian dalam Perkembangan Kota Nganjuk dan Pengaruhnya terhadap Perubahan Mata Pencaharian dan Pendapatan Petani. Diakses dari http://www.lib.itb.ac.id

Widjanarko et al (dalam ibrahim). 2006. Dampak Alih Fungsi Lahan. Dalam Penelitian Alih Fungsi Lahan di Pulau Jawa, Universitas Sumatra Utara.

Winoto. 2005. Fakta Alih Fungsi Lahan. Dalam Penelitian Alih Fungsi Lahan di Pulau Jawa, Universitas Sumatra Utara.

Yuhry,Muh. Taufiq, 2011. “Alih Fungsi Lahan Pertanian ke Non Pertanian," Dialektika. Edisi 08 (2011): 1-5.

Pewista, Ika and Rika Harini. Faktor dan 